\title{
Pengetahuan Ibu dan Penanganan Perkembangan Bahasa Anak di Desa Kalampa Kabupaten Bima Nusa Tenggara Barat
}

\author{
Ahmad $^{1(\mathrm{CA})}$, Aniharyati ${ }^{2}$ \\ ${ }^{1(\mathrm{CA})}$ Jurusan Keperawatan, Poltekkes Kemenkes Mataram, Indonesia; ahmadaisyah2014@ gmail.com \\ (Corresponding Author) \\ ${ }^{2}$ Jurusan Keperawatan, Poltekkes Kemenkes Mataram, Indonesia
}

\begin{abstract}
Development defined as the enhancement of body tool function that can be achieved through the body, maturity, and learning. Children were not as described by public as a passive, parasite, who always accept and never give, so there's a need of attention to development including language development that will determine the direction of further development in the life of children. The problem was how the relationship between mother's knowledge level of child language development with handling behavior. The benefits of research for the community was can increase knowledge of the mother about the behavior of handling the language development of children aged 1-4 Years, especially about the relationship of mother's knowledge about the development of the language of children with the behavior of language development of children Age 1 - 4 Years. Samples were taken from mothers who have children 1 - 4 years old in Kalampa Village District Woha. Data was analyzed and concluded by using a statistical test of Spearman rho and found that was a significant correlation between mother's knowledge about children language with behavior in handling to child language development with $p=0,025$ from standard of meaning level $\alpha=0,05$
\end{abstract}

\section{Keywords: Knowledge of language development; Child language development stimulation}

\begin{abstract}
ABSTRAK
Pengembangan didefinisikan sebagai peningkatan fungsi alat tubuh yang dapat dicapai melalui tubuh, kematangan, dan pembelajaran. Anak-anak tidak digambarkan oleh publik sebagai parasit, pasif, yang selalu menerima dan tidak pernah memberi, jadi ada kebutuhan untuk pengembangan termasuk pengembangan bahasa yang akan menentukan arah perkembangan selanjutnya dalam kehidupan anakanak. Masalahnya adalah bagaimana hubungan antara tingkat pengetahuan ibu tentang perkembangan bahasa anak dengan perilaku penanganan. Manfaat penelitian bagi masyarakat adalah dapat meningkatkan pengetahuan ibu tentang perilaku penanganan perkembangan bahasa anak usia 1-4 tahun, terutama tentang hubungan pengetahuan ibu tentang perkembangan bahasa anak dengan perilaku bahasa perkembangan anak Usia 1 - 4 Tahun. Sampel diambil dari ibu yang memiliki anak 1 - 4 tahun di Desa Kalampa Kecamatan Woha. Data dianalisis dan disimpulkan dengan menggunakan uji statistik Spearman rho dan menemukan bahwa ada hubungan yang signifikan antara pengetahuan ibu tentang bahasa anak dengan perilaku dalam menangani perkembangan bahasa anak dengan $\mathrm{p}=0,025$ dari standar tingkat makna $\alpha=0,05$
\end{abstract}

Kata kunci: Pengetahuan perkembangan bahasa; Penanganan perkembangan bahasa

\section{LATAR BELAKANG}

Perkembangan setelah tahun pertama ditandai oleh beberapa proses yang sangat mendasar, misalnya, perkembangan sosial dan pengembangan kepribadian yang ditandai oleh perkembangan perilaku menyimpang. Perilaku menyimpang harus tumbuh dan menjadi stabil sebagai latar belakang 
struktural perilaku masa depan. Pada tahun pertama, dasar harus dibuat untuk munculnya perilaku menyimpang yang nantinya akan memainkan peran penting sepanjang hidup (Cahyaningsih, 2014).

Pengetahuan dan perilaku ibu dalam merawat anak-anak mereka dapat diperkuat dan ditingkatkan, kesadaran masyarakat terutama ibu perlu ditingkatkan dengan mengetahui perkembangan setiap bahasa dalam setiap periode kehidupan, sehingga anak-anak akan mendapatkan hak mereka dalam perawatan, terutama dalam bahasa pengembangan yang akan menentukan kehidupan selanjutnya. Ketidaktahuan dan ketidaktahuan tentang bagaimana merawat dan mengetahui perkembangan bahasa anak-anak akan memiliki pengaruh buruk pada kehidupan anak berikutnya (Soetjiningsih, 2015). Peran perawat sebagai petugas kesehatan sangat penting dalam memberikan penjelasan kepada masyarakat tentang pentingnya pengetahuan pengembangan bahasa anak-anak, penanganan perilaku dalam pengembangan bahasa anakanak (Cahyaningsih, 2014).

\section{METODE}

Desain penelitian menggunakan pendekatan Cross-sectional yang mengukur Variabel Independen dengan Variabel Dependen pada saat yang sama (Burns and Grove, 2016). Tahap pertama para peneliti mengidentifikasi masalah bahasa anak-anak untuk mengetahui perkembangan bahasa anak-anak. Pada tahap kedua, para peneliti melakukan konseling bagi ibu yang memiliki anak usia 1-4 tahun di desa tanpa memperhatikan tahap perkembangan bahasa anak sesuai perkembangan usia. Tahap ketiga peneliti mengevaluasi kemampuan ibu untuk memahami perkembangan bahasa anak-anak

\section{HASIL}

Pada penyajian hasil. Data dikelompokan menjadi dua bagian, yaitu data umum dan data khusus. Data umum disajikan terlebih dahulu kemudian baru data khusus.

\section{Data Umum}

Tabel 1 Karakteristik Responden di desa Kalampa Kecamatan Woha Kabupaten Bima 2017.

\begin{tabular}{lcc}
\hline \multicolumn{1}{c}{ Karakteristik } & \multicolumn{2}{c}{$\mathrm{n}=80$} \\
\cline { 2 - 3 } Umur & Frekwensi & $\%$ \\
$15-19$ tahun & 8 & 10,0 \\
$20-35$ tahun & 37 & 46,2 \\
$>35$ tahun & 35 & 43,8 \\
\hline Tingkat Pendidikan & & 10 \\
SD & 8 & 15 \\
SMP & 12 & 62,5 \\
SMA & 50 & 12,5 \\
Diploma/Sarjana & 10 & \\
\hline Tempat mendapatkan informasi kesehatan & & 67,5 \\
Puskesmas/Posyandu & 54 & 32,5 \\
Radio/Televisi & 26 & - \\
Koran/Majalah & - &
\end{tabular}


Tabel 1 menunjukkan bahwa mayoritas responden berada dalam kelompok umur 20-35 tahun $(46,2 \%)$, berpendidikan SMA $(62,5 \%)$, dan tempat responden mendapatkan informasi kesehatan terbanyak adalah di Puskesmas/Posyandu, yaitu sebanyak 54 responden $(67,5 \%)$

\section{Data Khusus}

1). Pengetahuan Ibu tentang perkembangan bahasa anak

Tabel 2 Distribusi frekwensi responden berdasarkan pengetahuan tentang perkembangan bahasa anak di Desa Kalampa Kecamatan Woha Kabupaten Bima, Tahun 2017

\begin{tabular}{lccc}
\hline \multirow{2}{*}{ Tingkat Pengetahuan } & \multicolumn{2}{c}{$\mathrm{n}=80$} \\
\cline { 2 - 3 } & Frekwensi & $\%$ \\
\hline Baik & 30 & 37,4 \\
Cukup & 31 & 38,8 \\
Kurang & 19 & 23,8 \\
\hline
\end{tabular}

Dari tabel diatas menunjukkan bahwa sebanyak 30 responden $(37,4 \%)$ memiliki pengetahuan yang baik, dan sebanyak $31(38,8 \%)$ responden memiliki pengetahuan yang cukup dan sebanyak 19 responden $(23,8 \%)$ memiliki pengetahuan yang kurang tentang perkembangan bahasa anak.

2). Perilaku penanganan perkembangan bahasa anak usia $1-4$ tahun

Tabel 3 Distribusi frekwensi responden berdasarkan perilaku penanganan perkembangan bahasa anak di Desa Kalampa Kecamatan Woha Kabupaten Bima, Tahun 2017

\begin{tabular}{lcc}
\hline \multirow{2}{*}{ Perilaku penanganan perkembangan bahasa } & \multicolumn{2}{c}{$\mathrm{n}=80$} \\
\cline { 2 - 3 } & Frekwensi & $\%$ \\
\hline Baik & 50 & 62,5 \\
Cukup & 14 & 17,5 \\
Kurang & 16 & 20,0 \\
\hline
\end{tabular}

Dari tabel diatas terlihat bahwa sebanyak 50 responden $(62,5 \%)$ memiliki perilaku yang baik dalam penanganan perkembangan bahasa anak dan sebanyak 14 responden $(17,5 \%)$ memiliki perilaku yang cukup dan sebanyak 16 responden (20,0\%) memiliki perilaku yang kurang dalam penanganan pelrkembangan bahasa anak usia $1-4$ tahun.

3). Tabulasi silang antara pengetahuan ibu tentang perkembangan bahasa anak dengan perilaku penanganan perkembangan bahasa anak usia 1 - 4 tahun di Desa Kalampa Kecamatan Woha.

Tabel 4 Tabulasi silang antara pengetahuan ibu tentang perkembangan bahasa anak dengan perilaku penanganan perkembangan bahasa anak usia 1 - 4 tahun di Desa Kalampa Kecamatan Woha Kabupaten Bima, Tahun 2017

\begin{tabular}{|c|c|c|c|c|c|c|c|c|}
\hline \multirow{3}{*}{ Tingkat Pengetahuan } & \multicolumn{8}{|c|}{ Perilaku penanganan perkembangan bahasa $(n=80)$} \\
\hline & \multicolumn{2}{|c|}{ Baik } & \multicolumn{2}{|c|}{ Cukup } & \multicolumn{2}{|c|}{ Kurang } & \multicolumn{2}{|c|}{ Total } \\
\hline & $\mathrm{n}$ & $\%$ & $\mathrm{n}$ & $\%$ & $\mathrm{n}$ & $\%$ & $\mathrm{n}$ & $\%$ \\
\hline Baik & 23 & 28,7 & 4 & 5,0 & 3 & 3,8 & 30 & 37,4 \\
\hline Cukup & 17 & 21,3 & 9 & 11,2 & 5 & 6,2 & 31 & 38,8 \\
\hline Kurang & 10 & 12,5 & 1 & 1,3 & 8 & 10 & 19 & 23,8 \\
\hline
\end{tabular}


Dari tabel 5.7 diatas terlihat bahwa terbanyak responden memiliki pengetahuan yang baik dengan perilaku yang baik pula yaitu $23(28,7 \%)$ dan dari uji statistik spearman rho didapatkan bahwa terdapat hubungan yang signifikan antara pengetahuan ibu tentang perkembangan bahasa anak dengan perilaku penanganan perkembangan bahasa anak dimana $\mathrm{p}=0,025$ dengan standar tingkat kemaknaan $\alpha=0,05$

\section{PEMBAHASAN}

1. Pengetahuan ibu tentang perkembangan bahasa anak

Dari tabel di atas terlihat bahwa sebanyak 30 responden $(37,4 \%)$ memiliki pengetahuan yang baik, dan sebanyak 31 (38,8\%) responden memiliki pengetahuan yang cukup dan sebanyak 19 responden $(23,8 \%)$ memiliki pengetahuan yang kurang memadai tentang perkembangan bahasa anak. Hal ini menurut pendapat Tri Rusmi Widayatun 1990, yang mengatakan ada tiga perubahan yang dialami seseorang dalam pembelajaran, yaitu: perubahan karena proses psikologis, perubahan karena proses kedewasaan dan perubahan karena proses pembelajaran (Rusmini, 2009) .

Selain itu, keluarga (responden) mendapatkan pengetahuan tentang perkembangan bahasa anak-anak dari hasil belajar mereka / merasakannya ke berbagai informasi yang berkaitan dengan perkembangan anak-anak. Responden juga menerima informasi tentang perkembangan anak dari pendidikan kesehatan tentang perkembangan anak dari petugas kesehatan di posyandu / puskesmas / rumah sakit dan yang diterima melalui media massa seperti televisi, radio dan majalah, proses terjadinya pengetahuan dimulai dengan mendengar individu, membaca, atau melihat dari sumber informasi melalui pesan yang disampaikan oleh pengirim melalui media (Notoatmodjo, 2010).

2. Perilaku penanganan perkembangan bahasa pada anak usia $1-4$ tahun

Dari tabel di atas dapat dilihat bahwa sebanyak 50 responden $(62,5 \%)$ memiliki perilaku yang baik dalam menangani perkembangan bahasa anak-anak dan sebanyak 14 responden $(17,5 \%)$ memiliki perilaku yang cukup dan sebanyak 16 responden $(20,0 \%)$ memiliki perilaku yang kurang dalam menangani perkembangan bahasa untuk anak usia 1-4 tahun. Selain itu perilaku yang baik muncul dari keinginan para ibu untuk memberikan perawatan, bantuan, dan perlindungan bagi anggota yang sangat muda / balita (100\% responden adalah orang tua dari balita). Secara umum, keluarga bertanggung jawab untuk menciptakan dan memelihara kondisi fisik dan kesehatan serta pengembangan bahasa dalam mendukung perkembangan anak yang optimal. Ini terutama dilakukan oleh para ibu, seperti pendapat Nasrul Efendi, 1998, salah satu fungsi biologis keluarga adalah untuk memelihara, melindungi dan merawat anggota keluarga (Effendi, 1998).

Perilaku dalam menangani perkembangan bahasa adalah respons seseorang atau organisme terhadap rangsangan yang berkaitan dengan pertumbuhan, sistem perawatan kesehatan, makanan dan lingkungan (Notoatmodjo, 2003). Adanya respons atau perilaku (cara) yang sangat baik dari keluarga merupakan dampak positif dari keberadaan pengetahuan tentang perkembangan bahasa pada anak itu sendiri. 
3. Hubungan antara tingkat pengetahuan Ibu tentang perkembangan bahasa anak dengan perilaku dalam penanganannya pada pada anak usia 1-4 tahun

Responden memiliki pengetahuan yang baik dengan perilaku yang baik, yaitu $23(28,7 \%)$ dan dari uji statistik Spearman rho, ditemukan bahwa ada hubungan yang signifikan antara pengetahuan ibu tentang perkembangan bahasa anak-anak dan perilaku penanganan perkembangan bahasa anak-anak di mana $p=0,025$ dengan standar tingkat signifikansi $\alpha=0,05$. Hal ini terjadi karena keluarga memiliki pengetahuan tentang perkembangan bahasa sebagai hasil belajar, belajar itu sendiri dapat terjadi di lingkungan keluarga dan masyarakat sebagai pengaruh lingkungan. Selain dari terjadinya perilaku keluarga yang positif dalam menangani perkembangan bahasa anak-anak sebagai akibat dari pengaruh pengetahuan, itu juga kemungkinan akan dipengaruhi oleh faktor-faktor lain seperti karena pengalaman dan rasa tanggung jawab keluarga dalam merawat, memelihara dan melindungi anggotanya (Effendi, 1998).

Perilaku seseorang terhadap objek tertentu dipengaruhi oleh pengetahuannya tentang objek tersebut. perilaku itu sendiri dapat bersifat pasif (pengetahuan, motivasi, persepsi, dan sikap) atau aktif (dalam bentuk tindakan atau praktik nyata) (Notoatmodjo, 2010). Kemudian Lawrence Green 12 menganalisis perilaku manusia yang berangkat dari tingkat kesehatan. Bahwa kesehatan seseorang atau masyarakat dipengaruhi oleh dua faktor utama, yaitu faktor perilaku dan faktor di luar perilaku (Notoatmodjo, 2010).

\section{KESIMPULAN}

Berdasarkan hasil penelitian dan diskusi yang dijelaskan sebelumnya, kesimpulan dari penelitian ini akan dijelaskan sebagai berikut: (1). Tingkat pengetahuan yang diperoleh dari hasil penelitian ini menunjukkan bahwa rata-rata responden memiliki pengetahuan yang cukup dan baik tentang perkembangan bahasa anak, yaitu $38,8 \%$ dan $37,4 \%$. (2) Perilaku penanganan perkembangan bahasa anak sebagian besar memiliki perilaku yang baik dalam menangani perkembangan bahasa anak usia 1 4 tahun yaitu sebesar $62,5 \%$. (3) Dari uji statistik spearman rho, ditemukan bahwa ada hubungan yang signifikan antara pengetahuan ibu tentang bahasa ibu dan perilaku dalam menangani perkembangan bahasa anak dengan $p=0,025$ dari tingkat signifikansi standar $\alpha=0,05$.

Saran dari penelitian untuk masyarakat atau keluarga disarankan untuk lebih aktif dalam menemukan semua informasi yang dapat menambah pengetahuan mereka. Informasi dapat diperoleh di media massa, baik media cetak maupun elektronik kemampuan untuk menyelesaikan masalah kesehatan akan lebih baik jika didasarkan pada pengetahuan yang cukup dan umumnya, lembaga layanan kesehatan memberikan penyuluhan tentang pentingnya pengetahuan setiap perkembangan anak di masing-masing tumbuh dan berkembang sehingga mereka bisa mengetahui bentuk tindakan yang disesuaikan dengan tingkat perkembangannya, terutama perkembangan bahasa. 


\section{REFERENCES}

Burns and Grove's, 2016; Practice of Nursing Research edisi 8. Elsevier.

Dwi Sulistyo Cahyaningsih, S.Kp. 2014; Pertumbuhan Perkembangan anak dan Remaja, Jakarta: Trans Info Medika.

Nasrul Effendi. 1998; Keperawatan Kesehatan Masyarakat edisi 2. Jakarta: EGC.

Soetjiningsih., I G N. Gde Ranuh. 2015; Tumbuh kembang anak edisi 2. Jakata: EGC.

Soekidjo Notoatmodjo. 2010; Ilmu Perilaku Kesehatan, Jakarta: Rhineka Cipta.

Soekidjo Notoatmodjo. 2003; Pendidikan dan perilaku kesehatan,„Jakarta: Rhineka Cipta.

Tri Rusmini. 2009; Ilmu Perilaku MA 104 Buku Pegangan Mahasiswa Akper. Jakarta: Sagung Seto 